\title{
Comparing quartz silt surface microstructures in two sandy soils in young-glacial landscape of northern Poland
}

\begin{abstract}
The studies on quartz silt surface microstructures using scanning electron microscopy (SEM) were performed in Brunic Arenosol and Gleyic Ortsteinic Podzol, as major components of soil cover of the lower supra-flood terrace of the Słupia River, N Poland. Brunic Arenosols have developed from coarse- and medium-grained fluvioglacial sands, whereas Podzols from aeolian sands of mid-Holocene age, which in some places were covered with younger aeolian deposits. A group of at least 100 randomly selected grains from each soil horizon have been analyzed. The grains were classified into one of the following groups: fresh (type A), grains with the features of chemical weathering (type B), grains coated with scaly-grain incrustations (type C), grains coated with bulbous incrustations (type D), and cracked grains (type E). Parent materials of the investigated soils did not differ significantly in terms of contribution of grain types and type $\mathrm{C}$ predominated in both soils. Significant differences were noted in soil solums. Grains covered by scaly-grained incrustations predominated in Brunic Arenosol, which constituted $62-89 \%$. In the profile of Gleyic Ortsteinic Podzol grains type B predominated in $\mathrm{AE}$ and $\mathrm{E}$ horizons (65-82\%), whereas in the remaining horizons grains type $\mathrm{C}(54-77 \%)$.
\end{abstract}

Keywords: quartz surface microstructures, silt, SEM, Podzols, Brunic Arenosols

\section{INTRODUCTION}

Silica, as major component of rocks and sediments plays a crucial role in a global cycle of matter and pedogenesis (Tréguer and Pondaven 2000, Andrews and Schlesinger 2001). It is present in soils in biogenic and mineral forms, which can form many crystallographic phases from relative amorphous to pure crystalline, generating the different kind of energetic surfaces (Goyne et al. 2002) strongly influencing processes associated with the surface of solid phase, like sorption. Mineral phase of silica consists of primary and secondary minerals developed during pedogenesis (Monger and Kelly 2002) and quartz is mostly widespread of them.

Microstructures of quartz grain surfaces are shaped by a variety of physical, chemical and biochemical processes, including mechanical breakdown, dissolution, translocation, crystallizing and many others (Sommer et al. 2006). They are a product of weathering of solid rocks and their shards. Produced in this primary environment grains are characterized by angular shape and the presence of sharp edges, conchoidal fractures and shiny surfaces (Mycielska-Dowgiałło 2007, Degórski and Kowalkowski 2011, Woronko and Hoch 2011). During the transport they undergo rounding and frosting. The degree of roundness and frosting, as well as the character of microstructures observed on grain surfaces are predominantly conditioned by the type of transport (fluvial or aeolian) and its duration. There are also data which confirm selection of grains in terms of their size and roundness during this process (Niedziałkowska 1991). Occurring in deposits of various origin grains can still undergo post-depositional transformations, including development of a variety of incrustations and processes of physical and chemical weathering. Transport and post-depositional processes, including pedogenic ones are reflected in surface topography, which can be identified using scanning electron microscopy (SEM) (Whalley and Krinsley 1974, Kowalkowski et al. 1980, Kowalkowski and Brogowski 1983, Kowalkowski 1984, Black and Dudas 1987, Helland et al. 1997, Kowalkowski and Kocoń 1998, Joshi 2009, Degórski and Kowalkowski 2011, Degórski et al. 2013, Woronko et al. 2015).

SEM studies on quartz grains surface microstructures were focused mainly on coarse sand granulometric fraction $(0.5-1.0 \mathrm{~mm})$. Only a small part of them concerns silt, which in some deposits and developed from them soils constitutes important or even major fraction. However, these studies were focused on identification of micromorphological features in a context of origin 
and rarely chemistry of deposits and most of them were performed in loess (Smalley and Cabrera 1970, Cegła et al. 1971, Smith and Whalley 1981, Pye 1987, Tsoar and Pye 1987, Rywocka-Kenig 1997), and only a few in deposits of other origin (Haines and Mazullo 1988, Woronko 2007). Apart from a single cases (Jonczak 2015), there is no data on pedogenic transformations of micromorphological features of this fraction.

Our studies aimed to compare quartz silt surface micromorphology in two sandy soils (Brunic Arenosol and Gleyic Ortsteinc Podzol) occurring within the lower supra-flood terrace of the Shupia River in youngglacial landscape of Middle Pomerania, northern Poland.

\section{STUDY AREA}

Location of the investigated lower supra-flood terrace of the Stupia River and the studied soils is shown in figure 1 . This is an area characterizing by relatively mild climatic conditions, strongly influenced by Baltic Sea. Average annual temperatures in this area during 1950-2007 ranged from 6.0 to $9.7^{\circ} \mathrm{C}$ (average $7.8^{\circ} \mathrm{C}$ ) and annual precipitation $521.7-1260.5 \mathrm{~mm}$ (average
$793.8 \mathrm{~mm}$ ) (Kirschenstein and Baranowski 2008). The terrace has been developed in Late Pleistocene as a result of lowering of erosional base and development of meandering river channel (Florek 1991). Recently it is relatively plain area with irregularly distributed small mounds and depressions, characterized by absolute elevations between 17.5 and $20.5 \mathrm{~m}$ a.s.1. In its central part occur small peaty plain and in northern part many small terrain forms of anthropogenic origin, like drainage ditches, banks and just almost imperceptible remains of the small cemetery from the $19^{\text {th }}$ century. The terrace is built up from poorly and moderately sorted fluvioglacial sands, which thickness reaches four meters (Florek 1991). Intensification of aeolian processes, which had place about $4.2 \pm 0.63-$ $5.1 \pm 0.77 \mathrm{ka} \mathrm{BP}$ led to the formation of the covers of aeolian sands, which thickness rarely exceed 2 meters (Jonczak et al. 2013). The second intensification of aeolian processes took place about four hundred years ago and was associated probably with local deforestations. It was reflected by occurrence of thin (up to $30 \mathrm{~cm}$ ) aeolian covers.

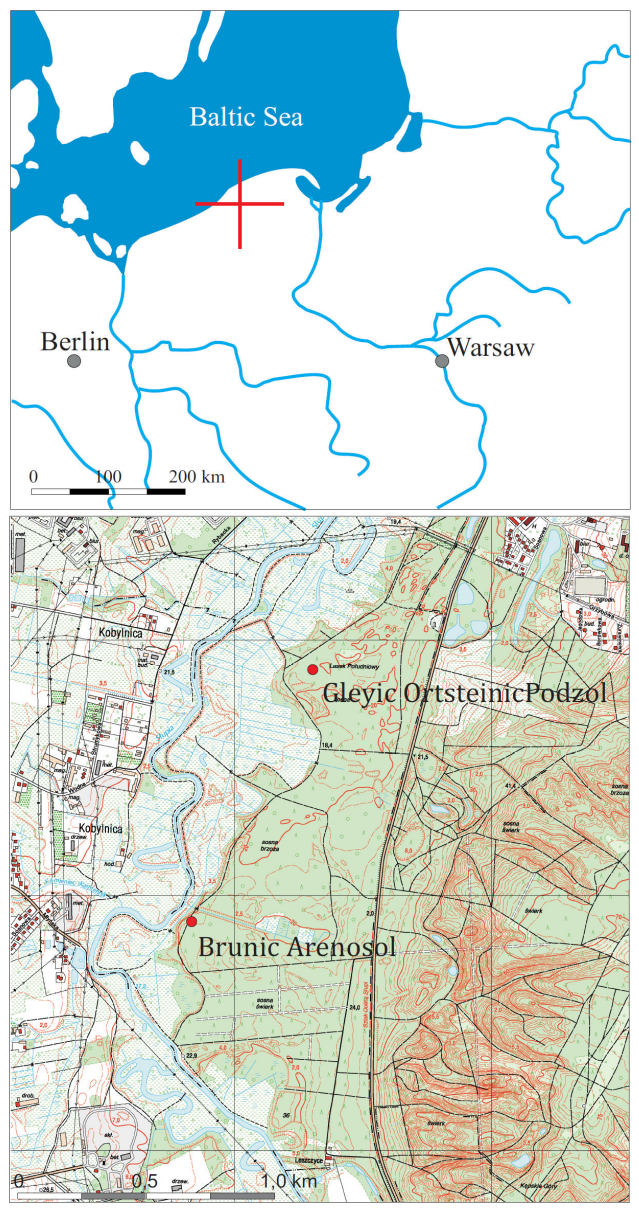

0

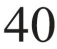

80

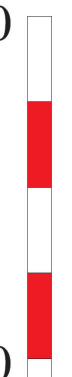

FIGURE 1. Location and morphology of the investigated soils
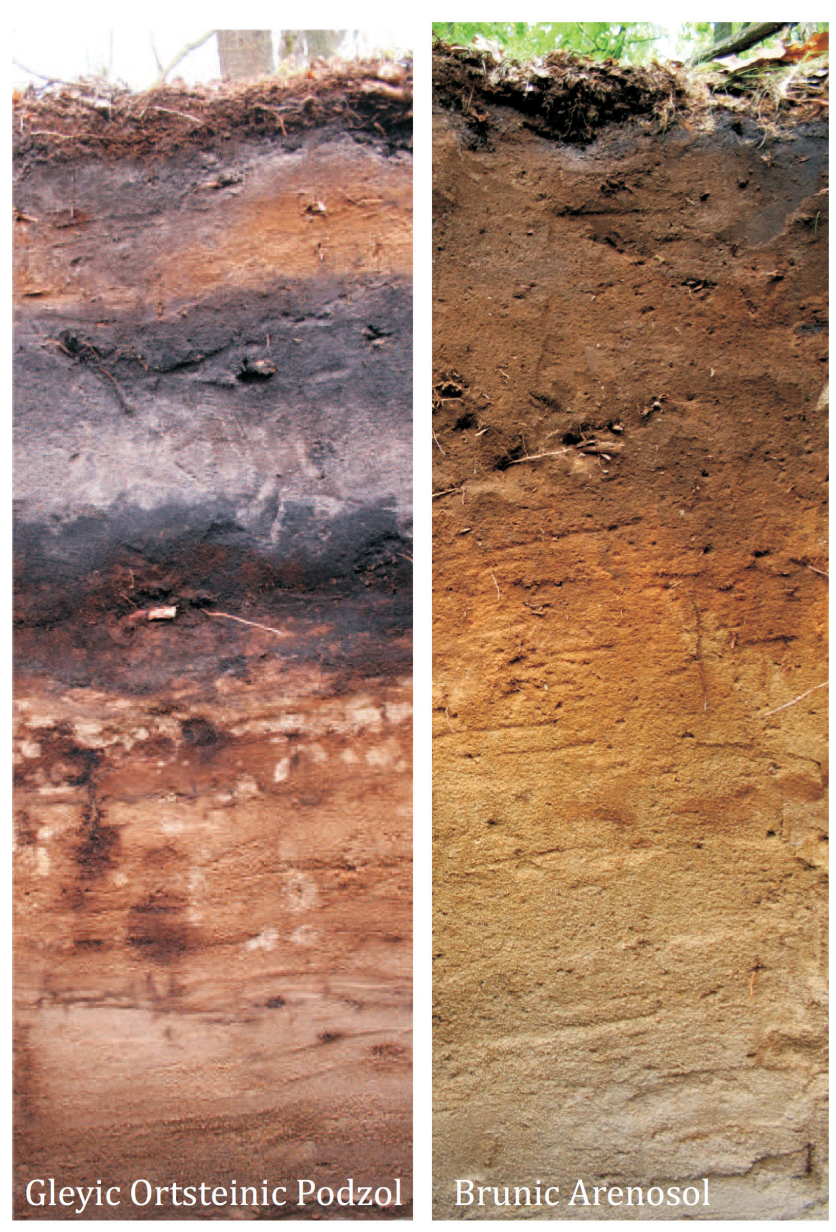
Brunic Arenosols associated with fluvioglacial sands and Gleyic Ortsteinic Podzols occurring within the aeolian sands are predominant components of soil cover of the lower supra-flood terrace. Both soil types have developed under the influence of high groundwater level. Nowadays, the area of terrace is almost completely afforested with Scots pine (Pinus sylvestris L.), in some places with admixtures of other tree species, like oak, birch and spruce.

\section{METHODS}

The soils were described using WRB classification system (IUSS Working Group WRB 2015). Two samples of undisturbed structure using $100 \mathrm{~cm}^{3}$ steel rings and one sample of disturbed structure were collected from each horizon. Samples of organic horizons after removing of fresh plant particles were dried in $65^{\circ} \mathrm{C}$ and milled into powder. Mineral samples were dried in $40^{\circ} \mathrm{C}$ and sieved through $2.0 \mathrm{~mm}$ sieve. The following analyses were performed in collected samples:

- bulk density by weight method in undisturbed samples,

- particle-size distribution by mixed sieve and pipette methods, applying division into granulometric fractions and textural groups after Polish Soil Science Society 2008 (PTG 2009),

- $\mathrm{pH}$ in water and $1 \mathrm{~mol} \cdot \mathrm{dm}^{-3}$ solution of $\mathrm{KCl}$, in a proportion soil: water $/ \mathrm{KCl}$ as $1: 10$ for organic samples and 1:2.5 for mineral samples,

- the content of total organic carbon (TOC) by Alten's method in organic samples and Tiurin method in mineral samples (Dziadowiec and Gonet 1999),

- the content of total nitrogen (TN) with Kjeldahl method (van Reeuvijk 2002) using distilling unit VELP UDK-127,

- the content of total iron $\left(\mathrm{Fe}_{\mathrm{t}}\right)$ by microwave plasma atomic emission spectrometry (Agilent 4100 MP-AES) after samples digestion in a mixture of $40 \% \mathrm{HF}$ and $60 \% \mathrm{HClO}_{4}$,

- the content of "free" iron oxides $\left(\mathrm{Fe}_{\mathrm{d}}\right)$ by microwave plasma atomic emission spectrometry (Agilent 4100 MP-AES) after samples extraction by Mehra and Jackson (1960) method,

Samples preparation and analysis of quartz silt surface micromorphology included:

- separation of $<0.05 \mathrm{~mm}$ granulometric fraction by dry sieving,

- purification with $10 \% \mathrm{HCl}$ solution (10 minutes at mild boiling temperature),

- washing five times with distilled water,

- separation of $0.05-0.02 \mathrm{~mm}$ fraction by sedimentation,
- drying in $40^{\circ} \mathrm{C}$,

- placing of randomly selected group of silt grains on microscope stage and vapouring with gold,

- performing a series of SEM images using microscope JEOL JSM-6610LV at magnifications 500x, containing a total of at least 100 pcs. of quartz grains,

- performing of SEM images at higher magnifications for exemplary grains for each type,

- classification of grains after Woronko (2007) into one of the following types: fresh/angular (type A), grains with the features of chemical weathering (type B), grains covered by scaly-grained incrustation (type C), grains covered by bulbous incrustation (type D) and cracked grains (type E).

\section{RESULTS}

\section{Properties of the soils}

Morphology of the studied soils is shown in Figure 1. The soils were characterized by the presence of mor type of humus and well developed, deep profiles (110 $\mathrm{cm}$ in Brunic Arenosol and $92 \mathrm{~cm}$ in Gleyic Ortsteinic Podzol). Both soils were developed from loose, medium and coarse sands of fluvioglacial in Brunic Arenosol and aeolian in Gleyic Orsteinic Podzol origin. The content of silt fraction $(0.05-0.02 \mathrm{~mm})$ ranged from 0.5 to $6.3 \%$ and from 0.4 to $4.3 \%$ respectively.

Brunic Arenosol was rich in TOC, which content in A1 horizon was $10.35 \mathrm{~g} \cdot \mathrm{kg}^{-1}$ and $7.29 \mathrm{~g} \cdot \mathrm{kg}^{-1}$ in A2 horizon. The content of TN was $0.70 \mathrm{~g} \cdot \mathrm{kg}^{-1}$ and 0.51 $\mathrm{g} \cdot \mathrm{kg}^{-1}$ respectively. A horizon gradually passed into $\mathrm{Bv}$ horizon of intense rusty color (table 1). The soil was strongly acidic (table 2 ), however $\mathrm{pH}$ increased with depth as a result of the influence of groundwater. Bulk density of the soil was typical for sandy soils and varied within the profile from 1.36 to $1.66 \mathrm{~g} \cdot \mathrm{cm}^{-3}$. Mineral substrates were strongly weathered, which is reflected in high values of $\mathrm{Fe}_{\mathrm{d}} / \mathrm{Fe}_{\mathrm{t}}$ ratio, reaching the highest values in $\mathrm{Bv}$ and $\mathrm{A} 2$ horizons.

The second profile represented the polycyclic pedocomplex of Gleyic Ortsteinic Podzol developed from aeolian sands and Podzol in initial stage of development associated with about $20 \mathrm{~cm}$ thick layer of aeolian sand covering the older soil. The soils were rich in TOC (23.46 $\mathrm{g} \cdot \mathrm{kg}^{-1}$ in AE horizon and 35.15 $\mathrm{g} \cdot \mathrm{kg}^{-1}$ in $2 \mathrm{AE}$ horizon) and relatively rich in nitrogen (1.40 $\mathrm{g} \cdot \mathrm{kg}^{-1}$ in AE horizon and $1.03 \mathrm{~g} \cdot \mathrm{kg}^{-1}$ in $2 \mathrm{AE}$ horizon). They were characterized by strongly acidic $\mathrm{pH}$, which slightly increases with depth (table 2). Free iron oxides showed vertical displacement typical for podzolization. Bulk density varied from 1.26 to 1.55 $\mathrm{g} \cdot \mathrm{cm}^{-3}$. 
TABLE 1. Physical properties of the soils studied

\begin{tabular}{|c|c|c|c|c|c|c|}
\hline Horizon & $\begin{array}{l}\text { Depth } \\
{[\mathrm{cm}]}\end{array}$ & $\begin{array}{l}\text { Deposits } \\
\text { origin }\end{array}$ & $\begin{array}{l}\text { Textural } \\
\text { group }\end{array}$ & $\begin{array}{l}\text { Content of silt } \\
(0.05-0.02 \mathrm{~mm}) \\
{[\%]}\end{array}$ & $\begin{array}{l}\text { Basic color of } \\
\text { moist soil } \\
\text { after Munsell }\end{array}$ & $\begin{array}{l}\text { Bulk density } \\
{\left[\mathrm{g} \cdot \mathrm{cm}^{-3}\right]}\end{array}$ \\
\hline \multicolumn{7}{|c|}{ Brunic Arenosol } \\
\hline A1 & $0-19$ & fluvioglacial & medium sand & 6.3 & 7.5YR 3/2 & 1.40 \\
\hline A2 & 19-31 & fluvioglacial & medium sand & 3.9 & 7.5YR 3/2.5 & 1.36 \\
\hline $\mathrm{ABv}$ & $31-45$ & fluvioglacial & coarse sand & 3.3 & $7.5 \mathrm{YR} 3 / 2$ & 1.37 \\
\hline $\mathrm{Bv}$ & $45-70$ & fluvioglacial & medium sand & 2.6 & 7.5 YR 3/4 & 1.45 \\
\hline $\mathrm{BvCg}$ & $70-110$ & fluvioglacial & coarse sand & 0.5 & 10YR 5/5 & 1.56 \\
\hline $\mathrm{Cg}$ & $110-150$ & fluvioglacial & coarse sand & 0.5 & $2.5 \mathrm{Y} 6 / 4$ & 1.53 \\
\hline \multicolumn{7}{|c|}{ Gleyic Ortsteinic Podzol } \\
\hline $\mathrm{AE}$ & $0-6$ & aeolian & medium sand & 0.4 & 7.5YR 3/1 & 1.26 \\
\hline Bhs & $6-18$ & aeolian & medium sand & 1.1 & $7.5 Y R$ 4/4 & 1.47 \\
\hline $2 \mathrm{AE}$ & $18-31$ & aeolian & medium sand & 1.0 & 7.5YR 2/1 & 1.37 \\
\hline $2 \mathrm{E}$ & $31-40$ & aeolian & medium sand & 1.0 & 7.5YR 4/1.5 & 1.39 \\
\hline 2Bhsg & $40-58$ & aeolian & medium sand & 4.3 & 7.5YR 1.7/1 & 1.48 \\
\hline 2Bhsg/C & $58-92$ & aeolian & medium sand & 0.8 & 10YR 4/4 & 1.51 \\
\hline $3 \mathrm{Cg}$ & $92-130$ & fluvioglacial & coarse sand & 0.7 & $10 \mathrm{YR} 4 / 3$ & 1.55 \\
\hline
\end{tabular}

TABLE 2. Chemical properties of the soils studied

\begin{tabular}{|c|c|c|c|c|c|c|c|c|}
\hline \multirow[t]{2}{*}{ Horizon } & Depth & \multirow[t]{2}{*}{$\mathrm{pH}_{\mathrm{H} 2 \mathrm{O}}$} & TOC & $\mathrm{TN}$ & \multirow[t]{2}{*}{ TOC:TN } & \multirow{2}{*}{\multicolumn{2}{|c|}{$\mathrm{Fe}_{\mathrm{t}}$}} & \multirow[t]{2}{*}{$\mathrm{Fe}_{\mathrm{d}} / \mathrm{Fe}_{\mathrm{t}}$} \\
\hline & {$[\mathrm{cm}]$} & & \multicolumn{2}{|l|}{$\left[\mathrm{g}^{\mathrm{kg}} \mathrm{kg}^{-1}\right]$} & & & & \\
\hline \multicolumn{9}{|c|}{ Brunic Arenosol } \\
\hline $\mathrm{Oi}$ & $9-6$ & 4.78 & 502.50 & 15.06 & 33.4 & 0.30 & - & - \\
\hline $\mathrm{Oe}$ & $6-4$ & 4.65 & 362.81 & 13.01 & 27.9 & 2.16 & - & - \\
\hline $\mathrm{Oa}$ & $4-0$ & 3.99 & 309.29 & 12.11 & 25.5 & 2.36 & - & - \\
\hline A1 & $0-19$ & 4.29 & 10.35 & 0.70 & 14.8 & 6.49 & 4.40 & 0.68 \\
\hline $\mathrm{A} 2$ & 19-31 & 4.56 & 7.29 & 0.51 & 14.4 & 7.91 & 6.80 & 0.86 \\
\hline $\mathrm{ABv}$ & $31-45$ & 4.69 & 5.12 & 0.32 & 16.0 & 6.23 & 4.12 & 0.66 \\
\hline $\mathrm{Bv}$ & $45-70$ & 4.54 & 3.23 & 0.21 & 15.2 & 9.21 & 8.06 & 0.88 \\
\hline $\mathrm{BvCg}$ & $70-110$ & 4.81 & - & - & - & 3.36 & 0.68 & 0.20 \\
\hline $\mathrm{Cg}$ & $110-150$ & 5.02 & - & - & - & 2.46 & 0.30 & 0.12 \\
\hline \multicolumn{9}{|c|}{ Gleyic Ortsteinic Podzol } \\
\hline $\mathrm{Oi}$ & 6-4 & 4.33 & 477.62 & 10.49 & 45.5 & 0.27 & - & - \\
\hline $\mathrm{Oe}$ & $4-3$ & 4.38 & 415.67 & 13.36 & 31.1 & 0.77 & - & - \\
\hline $\mathrm{Oa}$ & $3-0$ & 3.80 & 274.45 & 11.50 & 23.9 & 2.21 & - & - \\
\hline $\mathrm{AE}$ & $0-6$ & 3.80 & 23.46 & 1.40 & 16.7 & 2.35 & 0.94 & 0.40 \\
\hline Bhs & 6-18 & 4.26 & 7.17 & 0.37 & 19.2 & 3.13 & 1.25 & 0.40 \\
\hline $2 \mathrm{AE}$ & $18-31$ & 4.11 & 35.15 & 1.03 & 34.3 & 1.00 & 0.56 & 0.56 \\
\hline $2 \mathrm{E}$ & $31-40$ & 4.30 & 5.40 & 0.18 & 30.6 & 0.54 & 0.16 & 0.30 \\
\hline 2Bhsg & $40-58$ & 4.35 & 35.56 & 1.26 & 28.3 & 2.00 & 1.30 & 0.65 \\
\hline 2Bhsg/C & 58-92 & 4.95 & 3.31 & 0.16 & 20.4 & 2.32 & 0.41 & 0.17 \\
\hline $3 \mathrm{Cg}$ & $92-130$ & 4.85 & - & - & - & 1.83 & 0.24 & 0.13 \\
\hline
\end{tabular}

\section{Micromorphology of quartz silt surface}

The content of various types of quartz silt grains in parent materials of the investigated soils did not differ significantly. Grains covered by scaly-grained incrustations with considerable content of chemically weathered and small amounts of fresh ones (Table 3) predominated in both soils. A considerable differences were observed in solums of the soils. In Brunic Arenosol, grains type $\mathrm{C}$ predominated, constituting from $63 \%$ in A horizon to $89 \%$ in Bv horizon. Fresh type grains constituted $7-24 \%$ and grains with the features of chemical weathering 2-12\%. Type D grains were not observed and type E grains occurred in small amounts only in topsoil. Contribution of different grain types strongly varied among the profile of Gleyic Ortsteinic Podzol. The differences between the individual horizons involved mainly grains type B and C. In A and E horizons, chemically weathered grains predominated, whereas in B horizons grains covered with scaly-grained incrustations. This tendency was noticed both in Gleyic Ortsteinic Podzol and in the younger initial podzolic soil. 
TABLE 3. The content of quartz silt grains of various surface microstructure

\begin{tabular}{|c|c|c|c|c|c|c|}
\hline \multirow[t]{2}{*}{ Horizon } & \multirow{2}{*}{$\begin{array}{l}\text { Depth } \\
{[\mathrm{cm}]}\end{array}$} & \multicolumn{5}{|c|}{ The content of grain types [\%] } \\
\hline & & $\mathrm{A}$ & $\mathrm{B}$ & $\mathrm{C}$ & $\mathrm{D}$ & $\mathrm{E}$ \\
\hline \multicolumn{7}{|c|}{ Brunic Arenosol } \\
\hline A1 & $0-19$ & 24 & 12 & 63 & 0 & 1 \\
\hline A2 & $19-31$ & 10 & 9 & 81 & 0 & 0 \\
\hline $\mathrm{ABv}$ & $31-45$ & 14 & 2 & 84 & 0 & 0 \\
\hline $\mathrm{Bv}$ & $45-70$ & 7 & 4 & 89 & 0 & 0 \\
\hline $\mathrm{BvCg}$ & $70-110$ & 9 & 7 & 84 & 0 & 0 \\
\hline $\mathrm{Cg}$ & $110-150$ & 18 & 20 & 62 & 0 & 0 \\
\hline
\end{tabular}

\begin{tabular}{lcrrrrl}
\hline \multicolumn{6}{l}{ Gleyic Ortsteinic Podzol } & \\
$\mathrm{AE}$ & $0-6$ & 18 & 64 & 17 & 0 & 1 \\
$\mathrm{Bhs}$ & $6-18$ & 10 & 13 & 77 & 0 & 0 \\
2AE & $18-31$ & 15 & 82 & 3 & 0 & 0 \\
2E & $31-40$ & 5 & 80 & 15 & 0 & 0 \\
2Bhsg & $40-58$ & 4 & 29 & 67 & 0 & 0 \\
2Bhsg/C & $58-92$ & 16 & 30 & 54 & 0 & 0 \\
3Cg & $92-130$ & 8 & 27 & 65 & 0 & 0 \\
\hline
\end{tabular}

\section{DISCUSSION}

Quartz silt is a product of physical weathering of rocks and coarser granulometric fractions. Glacial and periglacial environments are the most effective in its production, where intense processes of frost weathering are running (Konishev 1982, Jefferson et al. 1997, Wright et al. 1998, Wright 2000). However, substantial amounts of silt grains can also be produced in aeolian (Krinsley and McCoy 1978, Bullard et al. 2004, Costa et al. 2013) and fluvial environments (Moss 1972, Moss and Green 1972, Moss et al. 1973). Newly produced grains (fresh or type A) are characterized by the presence of sharp edges, conchoidal fractures, microstairs and fracture faces, which microrelief is imperceptible even at high magnifications (figure 2). The contribution of this grain type in the studied soils

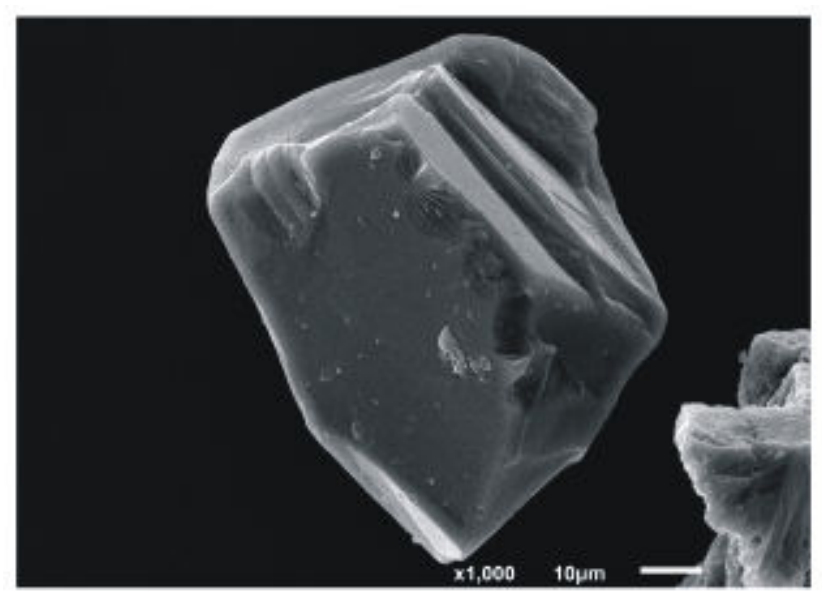

A (Gleyic Ortsteinic Podzol, AE horizon); B - scaly grain with microstairs on fracture faces (Gleyic Ortsteinic Podzol, 2AE horizon)

ranged from 4 to $24 \%$, reaching the largest amounts in parent materials and topsoil.

The remaining grain types are product of transformation of fresh ones, which can undergo destruction due to physical and chemical weathering or covering with crusts. Grains with the features of chemical weathering (type B) are characterized by the presence of numerous channel and point-negative forms of various sizes (figure 3 ). Chemical etching of quartz is accelerated by $\mathrm{pH}>9.0$ and $<3.5$ (Dove and Rimstidt 1994), humic substances and base cations (Dove 1999, Schulz and Whrite 1999). Moreover, temperature (Drees et al. 1989), living organisms (Leyval and Berthelin 1991) as well as mineralogy, which determines susceptibility to dissolution of different phases of silica play important role in etching. Higher solubility is typical for amorphous or biogenic silica as compared to crystalline $\mathrm{SiO}_{2}$ (Bartoli 1985, Drees et al. 1989). On the other hand, Gerard et al. (2002) reported that the highest amount of dissolved silica is produced in parent materials. Dissolved silica is adsorbed by many soil components, including carbonates, hydroxides of $\mathrm{Al}$ and oxides of $\mathrm{Fe}$ (Sommer et al. 2006). Its secondary crystallization on mineral surfaces leads to formation of amorphous shells and covers (Figure 4), which may take various forms, depending on conditions of crystallization and concentration of silica in solution. Particles of minerals, iron oxides and other soil components, including microorganisms (Bullard et al. 2004) are sometimes built-in in these crusts. Woronko (2007) distinguishes silt grains covered by scaly-grained (type C) and bulbous (type D) incrustations. The first type develop mainly in periglacial, not aggressive and abundant in fine mineral particles environments as a result of soil drying, which is associated with increasing concentration of solution and changes in $\mathrm{pH}$

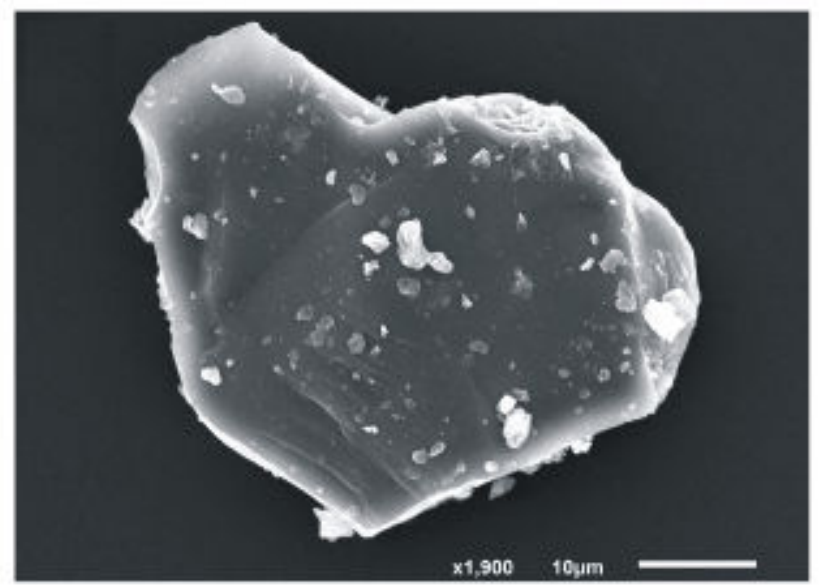

$\mathrm{B}$ 
A
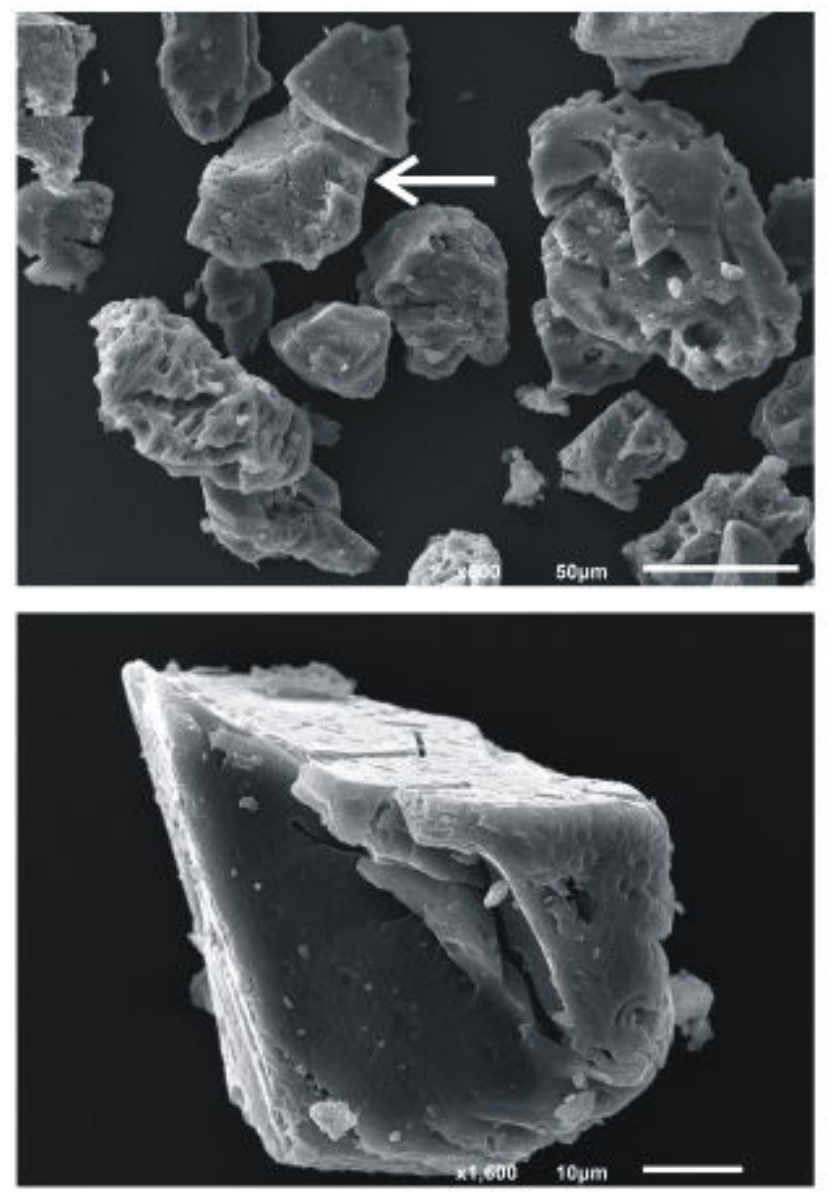

$\mathrm{C}$

FIGURE 3. SEM images of exemplary quartz silt grains type B: A - group of grains with the features of chemical weathering (Gleyic Ortsteinic Podzol, 2AE horizon); B - strongly etched surface of the grain from photo A indicated by the arrow at higher magnification; $\mathrm{C}$ - deep linear fissures of chemical weathering (Gleyic Ortsteinic Podzol, 2AE horizon); D - grain completely covered with the forms of chemical etching (Gleyic Ortsteinic Podzol, 2E horizon)
(Dietzel 2005). Bulbous incrustations develop in warm and dry climate zones as a result of etching of mineral surfaces by highly concentrated, strongly alkaline salt solutions and precipitation of dissolved silica in the periods of drought (Krinsley and McCoy 1978, Mycielska-Dowgiałło 1988).

Parent materials of the investigated soils, despite different origin, did not differ significantly in terms of percentage of various types of silt quartz grains. In both soils, grains covered by usually massive, scaly-grained incrustations with considerable content of chemically weathered and fresh ones (Table 3) predominated. The presence of grains with morphological features developed by chemical weathering in parent materials can be conditioned by the influence of enriched in labile fractions of soil organic matter (mainly fulvic acids) percolating rain waters or/and ground waters. The role of humic substances in quartz weathering is confirmed by results of the studies of Dove (1999) and Schulz and Whrite (1999).
B
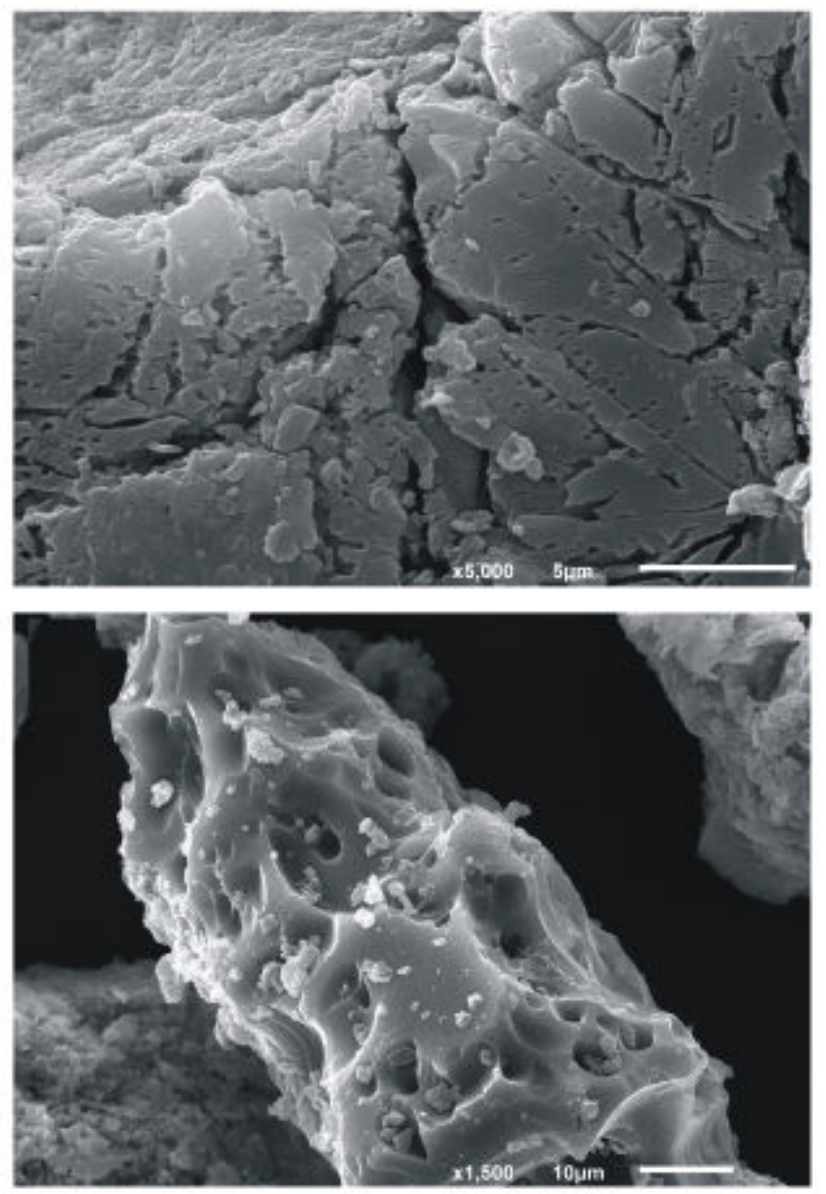

$\mathrm{D}$
A considerable differences in terms of percentage of different grain types were noted in horizons transformed in pedogenic processes (table 3 ). Predominance of grains with chemically weathered surfaces we noticed in AE, 2AE and 2E horizons of Gleyic Ortsteinic Podzol, whereas in A1 and A2 horizons of Brunic Arenosols their contribution ranged just from 9 to $12 \%$. The observed differenced cannot be explained by differences in $\mathrm{pH}$, which is only slightly lower in Podzol as compared to Arenosol. It might be an effect of differences in quantitative and qualitative features of soil organic matter, which occurs in higher amounts in Podzol. Humic substances in this soil can also be more aggressive. An interesting observation was that in topsoil of both soils were noted the highest contents of fresh grains. It can suggest supplying with fresh materials of aeolic origin in modern times. B horizons both in Gleyic Ortsteinic Podzol and Brunic Arenosol were dominated by grains of type $C$. Grain surfaces in these horizons were covered with mas- 
A
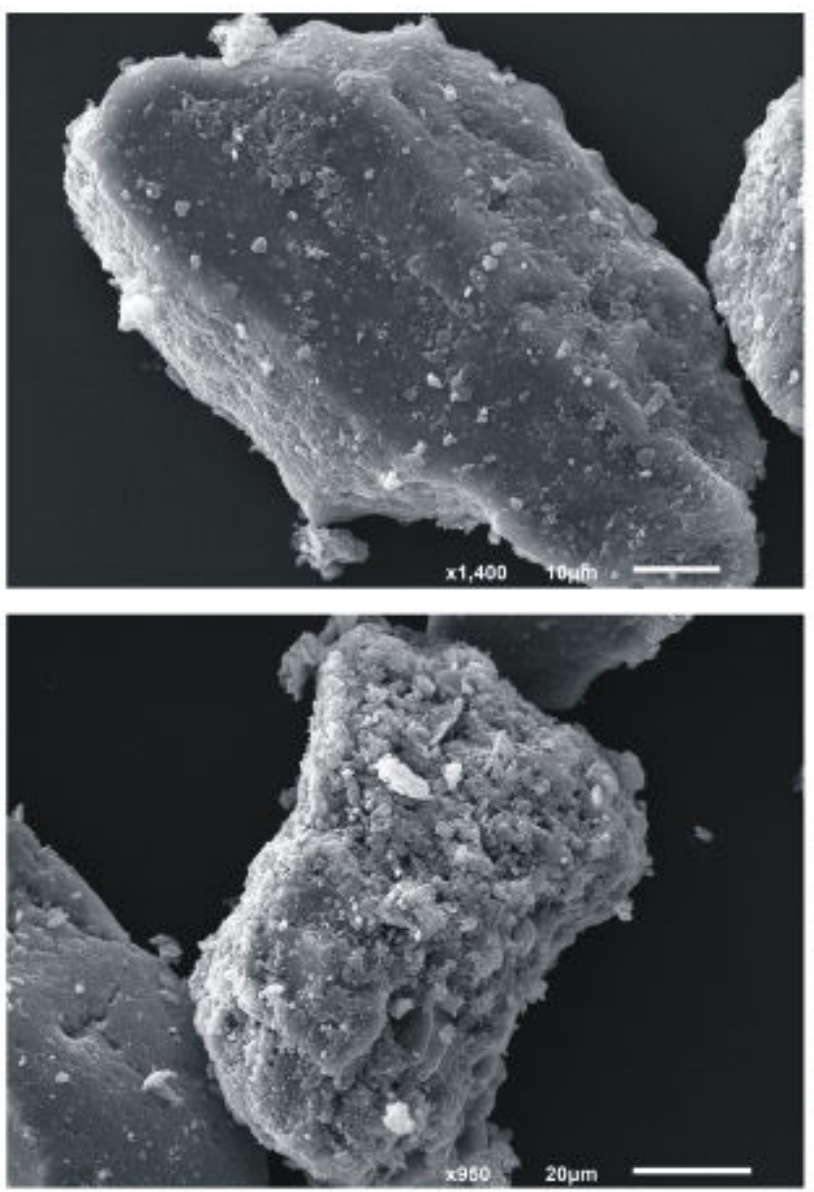

$\mathrm{C}$

FIGURE 4. SEM images of exemplary quartz silt grains type C: A - grain almost completely covered by relatively homogenous scaly-grained incrustation (Brunic Arenosol, A2 horizon); B - grain completely covered by thick, massive scaly-grained incrustation (Gleyic Ortsteinic Podzol, 3Cg horizon); C - grain completely covered by massive scaly-grained incrustation with built in it mineral particles and microorganisms (Gleyic Ortsteinic Podzol, Bhs horizon); D - a fragment of grain from photo C at higher magnification

sive silicate incrustations of porous structure with particles of clay minerals, fine silt and sometimes microorganisms built in incrustations. Vertical distribution of quartz silt grain types within the profile of Gleyic Ortsteinic Podzol suggests that pedogenic transformation of their surface micromorphology can be done in relatively short time, which is confirmed by earlier studies of the present author (Jonczak 2015). The problem of pedogenic transformation of quartz silt surface microrelief, including directions and intensity of the process requires broader studies, both in laboratory experiments and field studies on different soil types of particular climatic zones and developed from parent materials of different origin. Results of these studies would specify usefulness of silt quartz micromorphological features as indicators of pedogenic processes and introduce new information for interpretation of some soils physical and chemical properties, particularly specific surface area and cation exchange
B
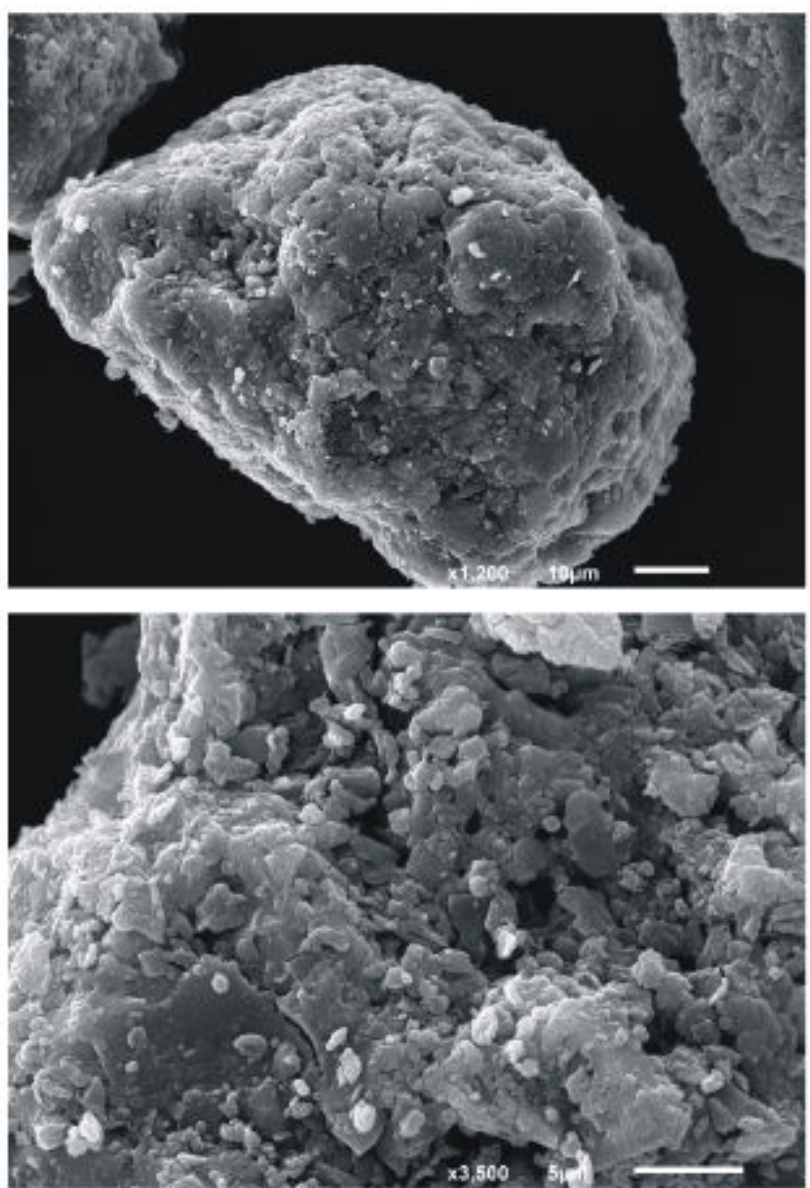

D

capacity. Interrelationships between micromorphological features of the surface of soil mineral components and properties mentioned above are obvious, however they are not identified quantitatively.

\section{CONCLUSIONS}

Foregoing preliminary studies prove importance of soil-forming processes on quartz silt surface microstructure. In the investigated Brunic Arenosol and Gleyic Ortsteinic Podzol, which were characterized by similar $\mathrm{pH}$ (3.99-5.02 and 3.80-4.95 respectively) and significantly differed in the content of soil organic matter, the differences concerned mainly contribution of the grains with features of chemical weathering and covered with scaly-grained incrustations. Grains covered with incrustations predominated in whole profile of Brunic Arenosol at variable contribution of fresh and chemically weathered ones. A similar 
regularities were noticed in $\mathrm{B}$ horizons of Gleyic Ortsteinic Podzol. In A and E horizons of that soil, grains with chemically weathered surfaces predominated.

\section{REFERENCES}

Andrews J.A., Schlesinger W.H., 2001. Soil $\mathrm{CO}_{2}$ dynamics, acidification, and chemical weathering in a temperate forest with experimental $\mathrm{CO}_{2}$ enrichment. Global Biogeochemical Cycles 15: 149-162.

Bartoli F., 1985. Crystallochemistry and surface properties of biogenic opal. Journal of Soil Science 36: 335-350.

Black J.M.W., Dudas M.J., 1987. The scanning electron microscopic morphology of quartz in selected soils from Alberta. Canadian Journal of Soil Science 67: 965-971.

Bullard J.E., Mctanish G.H., Pudmenzky C., 2004. Aeolian abrasion and models of fine particle production from natural red dune sand: and experimental study. Sedimentology 51: 1103-1125.

Cegła J., Buckley T., Smalley I.J., 1971. Microtextures of particles from some European loess deposits. Sedimentology 17: 129-134.

Costa P.J.M., Andrade C., Mahaney W.C., Marques da Silva F., Freire P., Freitas M.C., Janardo C., Oliviera M.A., Silva T., Lopez V., 2013. Aeolian microtextures of silica spheres inducted in a wind tunnel experiment: Comparison with aeolian quartz. Geomorphology 180/181: 120-129.

Degórski M., Kowalkowski A., 2011. The use of SEM morphoscopy in researching the litho-pedogenetic environments of Late Pleistocene and Holocene. Geographia Polonica 84(1): $17-38$.

Degórski M., Kowalkowski A., Kozłowska A., 2013. Podzolic Earths - geographical trends and discontinuities in the development. SEDNO Wydawnictwo Akademickie, Warszawa.

Dietzel M., 2005. Impact of cyclic freezing on precipitation of silica in $\mathrm{Me}-\mathrm{SiO}_{2}-\mathrm{H}_{2} \mathrm{O}$ system and geochemical implications for cryosoils and sediments. Chemical Geology 216: 79-88.

Dove P.M., 1999. The dissolution kinetics of quartz in aqueous mixed cation solutions. Geochimica et Cosmochimica Acta 63: 3715-3727.

Dove P.M., Rimstidt J.D., 1994. Silica-water interaction. Reviews in Mineralogy and Geochemistry 29: 259-308.

Drees L.R., Wilding L.P., Smeck N.E., Sankayi A.L., 1989. Silica in soils: Quartz and disordered silica polymorphs. [In:] Minerals in soil environments (Dixon J.B., Weed S.B., Editors). SSSA Book series No.1, Madison, WI.

Dziadowiec H., Gonet S.S. (Eds.), 1999. Methodological guide for soil organic matter surveys. Prace Komisji Naukowych Polskiego Towarzystwa Gleboznawczego 120, Warszawa.

Florek W., 1991. Postglacial development of river valleys in the middle part of the northern slope of Pomerania. WSP, Słupsk.

Gerard F., Francois M., Ranger J., 2002. Processes controlling silica concentration in leaching and capillary soil solutions of an acidic brown forest soil (Rhone, France). Geoderma 107: 197-226.

Goyne K.W., Zimmerman A.R., Newalkar B.L., Komarneni S., Brantley S.L., Chorover J., 2002. Surface charge of variable porosity $\mathrm{Al}_{2} \mathrm{O}_{3}(\mathrm{~s})$ and $\mathrm{SiO}_{2}(\mathrm{~s})$ adsorbents. Journal of Porous Materials 9(4): 243-256.

Haines J., Mazullo J., 1988. The original shapes of quartz silt grains: a test of the validity of the use of quartz grain shape analysis to determinate the sources of terrigenous silt in marine sedimentary deposits. Marine Geology 78: 227-240.
Helland P.E., Huang P-H., Diffendal Jr. R.F., 1997. SEM analysis of quartz sand grain surface textures indicates alluvial/colluvial origin of the Quaternary "glacial” boulder clays at Huangshan (Yellow Mountain), East-Central China. Quaternary Research 48: 177-186.

IUSS Working Group WRB, 2015. World Reference Base for Soil Resources 2014, update 2015. International soil classification system for naming soils and creating legends for soil maps. World Soil Resources Reports No. 106. FAO, Rome.

Jefferson I.F., Jefferson B.Q., Assallay A.M., Smalley I.J., 1997. Crashing of quartz sand to produce soil particles. Naturwissenschaften 84: 148-149.

Jonczak J., 2015. Genesis, evolution and properties of the soils of headwater valleys in young glacial lacustrine plains on the example of the Leśna Creek (Sławno Plain). Wydawnictwo Naukowe Akademii Pomorskiej w Słupsku, Słupsk.

Jonczak J., Olszak I., Łazarczyk A., 2013. Genesis, evolution and properties of soils of lower supra-flood terrace of the Shupia River in southern part of Słupsk. [In:] Środowisko glebotwórcze i gleby dolin rzecznych (Jonczak J., Florek W., Editors). Wydawnictwo Naukowe Bogucki, Poznań: 57-66.

Joshi V.U., 2009. Grain surface features of alluvial sediments of Upper Pravara basin and their environmental implications. Journal of the Geological Society of India 74: 711-722.

Kirschenstein M., Baranowski D., 2008. Annual precipitation and air temperature fluctuations and change tendencies in Słupsk. Dokumentacja Geograficzna 37: 76-82.

Konishev V.N., 1982. Characteristics of cryogenic weathering in the permafrost zone of the European USSR. Arctic, Anthartic and Alpine Research 14: 261-265.

Kowalkowski A., 1984. Surface texture of quartz grains from tundra soils under electron microscope. Quaternary Studies in Poland 5: 75-79.

Kowalkowski A., Brogowski Z., 1983. Features of cryogenic environment of soils of continental tundra and arid steppe on the southern Khangai slope under the electron microscope. Catena 10: 199-205.

Kowalkowski A., Kocoń J., 1998. Microtextures of cryopedogenic weathering in soils of the mountain Tundra of Middle Sweden. Roczniki Gleboznawcze - Soil Science Annual 49(1-2): 53-59.

Kowalkowski A., Mycielska-Dowgiałło E., Krzywobłocka-Laurow R., Wichrowska M., 1980. Analysis of surface textures of quartz sand grains observed in the electron microscope from the tundra and arid steepe soils of the Khangai Mts. Studia Geomorphologica Carpatho-Balcanica 14: 135-155.

Krinsley D., McCoy F., 1978. Aeolian quartz sand and silt [In:] Scanning electron microscopy in study of sediments (Whalley B.H., Editor). GeoAbstracts: 249-261.

Leyval C., Berthelin J., 1991. Weathering of mica by roots and rhizospheric microorganisms of pine. Soil Science Society of America Journal 55: 1009-1016.

Mehra O., Jackson J., 1960. Iron oxide removal from soils and clays by a dithionite-citrate system buffered with sodium bicarbonate. Clay and Clays Minerals 5: 317-327.

Monger H.C., Kelly E.F., 2002. Silica minerals [In:] Soil mineralogy with environmental applications (Dixon J.B., Schulze D.G., Editors). Book Series SSSA No.7, Madison, WI.

Moss A.J., 1972. Initial fluviatile fragmentation of granitic quartz. Journal of Sedimentary Petrology 42: 905-916.

Moss A.J., Green P., 1972. Sand and silt grains: predetermination of their formation and properties by macrofactures in quartz. Journal of Geological Society 22: 485-495. 
Moss A.J., Walker P.H., Hutka J., 1973. Fragmentation of granitic quartz in water. Sedimentology 20: 489-511.

Mycielska-Dowgiałło E., 1988. Relief features of the surface of the quartz grains of beaches in different climatic regions of the world. [In:] Geneza osadów i gleb w świetle badań w mikroskopie elektronowym (Mycielska-Dowgiałło E., Editor). Wydawnictwo Uniwersytetu Warszawskiego, Warszawa: 27-46.

Mycielska-Dowgiałło E., 2007. Methodology for studying textural parameters of clastic deposits. [In:] Badania cech teksturalnych osadów czwartorzędowych i wybrane metody oznaczania ich wieku (Mycielska-Dowgiałło E., Rutkowski J., Editors). Wydawnictwo Szkoły Wyższej Przymierza Rodzin Warszawa: 95-180.

Niedziałkowska E., 1991. The textural diversity of upper Quaternary fluvial deposits in the Carpathian Foreland. Geographical Studies 6: 119-146.

PTG, 2009. Classification of texture of soils and mineral deposits - PTG 2008, Roczniki Gleboznawcze - Soil Science Annual 60(2): 5-17.

Pye K., 1987. Aeolian dust and dust deposits. Academic Press, London.

Rywocka-Kenig K., 1997. Surface microtextures of quartz grains from loesses. Prace Państwowego Instytutu Geologicznego 155.

Schluz M.S., Whrite A.F., 1999. Chemical weathering in tropical watershed. Luquillo Mountains, Puerto Rico III: Quartz dissolution rates. Geochimica et Cosmochimica Acta 63: 337350 .

Smalley I.J., Cabrera I.J., 1970. The shape and surface texture of loess particles. Geological Society of America Bulletin 81: 1591-1595.

Smith B.J., Whalley W.B., 1981. Late Quaternary drift deposits of north-central Nigeria examined by scaning electron microscopy. Catena 8: 345-368.
Sommer M., Kaczorek D., Kuzyakov Y., Breuer J., 2006. Silicon pools and fluxes in soils and landscapes - a review. Journal of Plant Nutrition and Soil Science 169(3): 310-329.

Tréguer P., Pondaven P., 2000. Silica control of carbon dioxide. Nature 406: 358-359.

Tsoar H., Pye K., 1987. Dust transport and the question of desert loess formation. Sedimentology 34: 139-153.

Van Reeuvijk L.P., 2002. Procedures for soil analysis. Sixth edition. ISRiC, FAO, Wageningen.

Whalley W.B., Krinsley D.H., 1974. A scanning electron microscope study of surface textures of quartz grains from glacial environments. Sedimentology 21: 87-105.

Woronko B., 2007. Micromorphology types of quartz grains surface of silt fraction of their interpretative meaning. [In:] Badania cech teksturalnych osadów czwartorzędowych i wybrane metody oznaczania ich wieku (Mycielska-Dowgiałło E., Rutkowski J., Editors). Wydawnictwo Szkoły Wyższej Przymierza Rodzin, Warszawa: 181-204.

Woronko B., Hoch M., 2011. The development of frost-weathering microstructures on sand-sized quartz grains: Examples from Poland and Mongolia. Permafrost and Periglacial Processes 22: 214-227.

Woronko B., Pisarska-Jamroży M., van Loon A.J., 2015. Reconstruction of sediment provenance and transport processes from the surface textures of quartz grains from Late Pleistocene sandurs and an ice-marginal valley in NW Poland. Geologos 21(2): 105-115.

Wright J., 2000. The spalling of overgrowths experimental freezethaw of a quartz sandstone as a mechanism of quartz silt production. Micron 31: 631-638.

Wright J., Smith B., Whalley B., 1998. Mechanism of loess-sized quartz silt production and their relative effectiveness: laboratory simulations. Geomorphology 23: 669-680.

Received: June 27, 2016

Accepted: November 3, 2016

\section{Porównanie cech ultramorfoskopowych powierzchni ziaren pyłu kwarcowego $w$ dwóch glebach piaszczystych w młodoglacjalnym krajobrazie Polski pólnocnej}

Streszczenie: Badania miały na celu porównanie cech ultramorfoskopowych powierzchni ziaren pyłu kwarcowego w glebach rdzawych i glejobielicowych orsztynowych, stanowiących dominujące składniki pokrywy glebowej niższej terasy nadzalewowej rzeki Słupi na południe od Słupska. Gleby rdzawe związane są z pokrywami grubo- i średnioziarnistych piasków fluwioglacjalnych, zaś gleby glejobielicowe orsztynowe z występującymi w postaci niewielkich płatów pokrywami piasków eolicznych wieku środkowo-holoceńskiego, miejscami przykrytymi młodszymi osadami o tej samej genezie. Cechy ultramorfoskopowe badano z zastosowaniem skaningowej mikroskopii elektronowej (SEM) dla co najmniej 100 losowo wybranych ziaren pyłu w każdym wydzielonym poziomie genetycznym. Na podstawie dominujących cech, ziarna klasyfikowano do jednej z pięciu grup: świeże (typ A), z cechami wietrzenia chemicznego (typ B), pokryte skorupą łuskowo-ziarnistą (typ C), pokryte skorupą bulwiastą (typ D) oraz przełamane (typ E). Materiały macierzyste badanych gleb nie różniły się znacząco pod względem udziału poszczególnych typów ziaren. W obydwu glebach zdecydowanie dominowały ziarna typu C. Istotne różnice stwierdzono natomiast w solum gleb. W glebach rdzawych dominowały ziarna pokryte skorupą łuskowo-ziarnista, których udział w zależności od poziomu wynosił $62-89 \%$. W poziomach AE i E gleby glejobielicowej orsztynowej dominowały ziarna typu B (65-82\%), zaś w pozostałych poziomach typu C (54-77\%).

Słowa kluczowe: cechy ultramorfoskopowe, pył, SEM, gleby glejobielicowe, gleby rdzawe 